\title{
O bibliotecário jurídico da cidade de São Paulo: um estudo comparativo
}

\author{
Daniela Majorie Akama dos Reis \\ Universidade Estadual Paulista, Faculdade de Filosofia e Ciências, Departamento de Ciência da \\ Informação, Marília, SP, Brasil \\ danielamajorie@yahoo.com.br \\ Paula Drumond Sales Catarino \\ Lobo de Rizzo Sociedade de Advogados, São Paulo, SP, Brasil \\ paula.drumond@icloud.com
}

DOI: https://doi.org/10.265/rici.v13.n2.2020.18960

Recebido/Recibido/Received: 2018-11-09

Aceitado/Aceptado/Accepted: 2020-03-09

Resumo: Abordam-se os conceitos do profissional bibliotecário e de sua especialidade na área jurídica. Serão apresentados dados estatísticos destes profissionais do estado de São Paulo, e é feita uma comparação com dados de estudo anterior. É dado enfoque aos profissionais de bibliotecas jurídicas, nos serviços em suas rotinas, e as dificuldades no caminho profissional. Os resultados apresentam a diversidade de perfis e de serviços oferecidos pelos bibliotecários jurídicos de São Paulo. Palavras-chave: Biblioteca jurídica. Perfil profissional. Bibliotecário jurídico.

The Law librarian in the state of São Paulo: a comparative study

Abstract: This article deals with the concepts of the librarian as a professional and his specialty in the legal area. Statistical data will be presented about these professionals from the state of Sao Paulo, and a comparison is made with previous study data. We focus on the law library professionals, their routines and services, and the difficulties in their professional path. The results show the diversity of profiles and services offered by the Sao Paulo law librarians.

Keywords: Law library. Professional profile. Law librarian.

\section{El bibliotecario jurídico en el estado de São Paulo: un estudio comparativo}

Resumen: En este artículo se abordan los conceptos del profesional bibliotecario y de su especialidad en el área jurídica. Se presentarán datos estadísticos de estos profesionales del estado de São Paulo, y se hace una comparación con datos de estudio anterior. Se da enfoque a los profesionales de bibliotecas jurídicas, en los servicios en sus rutinas, y las dificultades en el camino profesional. Los resultados muestran la diversidad de perfiles y servicios ofrecidos por los bibliotecarios legales de Sao Paulo.

Palabras-clave: Biblioteca jurídica. Perfil profesional. Bibliotecario jurídico.

\section{Introdução}

O bibliotecário é um profissional que possui ampla gama de atuação. A profissão vai muito além do estereótipo da mulher idosa que pede silêncio na biblioteca. Blattmann, (2000, p. 45) explica que “os valores estão rompidos e o bibliotecário hoje não é o 'almoxarife' de livros e sim o gerente da informação". 
A biblioteca é um dos mais antigos sistemas de informação e é conceituada por muitos autores, de modo consensual, como um local que reúne informações para satisfazer as necessidades do usuário desta (CARVALHO, 2000, p. 2). Existem bibliotecas de vários tipos, como as públicas, especializadas, escolares e universitárias.

O campo de atuação do bibliotecário está diretamente ligado à sua prática e experiência. Sabe-se que há uma limitação na orientação aos bibliotecários em formação sobre os tipos de bibliotecas, durante o ensino superior. O bibliotecário recebe orientações técnicas e teóricas durante o curso de graduação, mas é no mercado de trabalho que eles vivenciarão as rotinas dos diferentes tipos de biblioteca. Este fato é prejudicial para a atuação do bibliotecário recém-formado.

Entende-se que o bibliotecário jurídico é o profissional com bacharelado em Biblioteconomia atuante em instituições relacionadas ao Direito. Edilenice Passos (2001, p. 1) define o bibliotecário jurídico como o "profissional que facilita o acesso à informação jurídica de forma ágil e eficiente". Para Mendes (2010, p. 2), este profissional pode atuar em "bibliotecas universitárias, bibliotecas de tribunais, fóruns, escritórios de advocacia, órgãos governamentais e não governamentais".

A evolução das ferramentas, tecnologia e serviços na Biblioteconomia obriga os profissionais desta área (assim como em outras) a se manterem constantemente atualizados, visando atender seus usuários adequadamente. Segundo Cunha $(2007$, p. 2), "as mudanças tecnológicas alteram, de forma drástica, as práticas profissionais em todas as áreas do conhecimento, repercutindo amplamente no mundo do trabalho que se encontra em reorganização trazendo insegurança aos profissionais". O bibliotecário jurídico, como profissional altamente especializado, necessita se adaptar conforme as novas demandas de seu público.

Isto posto, propôs-se mapear os serviços atuais dos bibliotecários do domínio jurídico do estado de São Paulo, com base no perfil destes profissionais, comparando os resultados com os do artigo de Baptista et al. (2008) ${ }^{1}$.

Autores como Passos (2001), Loureiro (2005), Baptista (2008), Costa (2010), Mendes (2010) e Paiva e Pother (2011), realizaram estudos sobre o bibliotecário jurídico. Dentre estes, o artigo de Baptista et al. (2008²), apresenta informações contendo dados quantitativos de bibliotecários jurídicos. As autoras apresentam dados relacionados às competências dos

\footnotetext{
${ }^{1}$ Pesquisa ambientada no Distrito Federal, publicada em 2008.

2 BAPTISTA, S.; PASSOS, E. J. L.; SOARES, M. G.; SOUSA, L. O perfil do bibliotecário que atua na área jurídica, no Distrito Federal: relato de pesquisa. Revista Ibero-americana de Ciência da Informação (RICI), Brasília, v. 1, n. 2, p. 151-174, dez. 2008. Disponível em: http://repositorio.unb.br/bitstream/10482/12986/1/ARTIGO PerfilBibliotecarioArea.pdf. Acesso em: 16 jan. 2019.
} 
bibliotecários, como perfil, salários, educação continuada, dados sobre formação e emprego. Com a análise dos dados, chegaram à conclusão de que a maioria dos bibliotecários jurídicos do Distrito Federal: são do gênero feminino, a maioria das atividades exercidas são relacionadas ao tratamento de documentos, há pouco investimento em educação continuada, muitos profissionais têm dificuldade em relação à linguagem específica do domínio jurídico e mais da metade não tem segunda graduação.

Este trabalho justifica-se na medida em que se notou a necessidade da coleta de dados estatísticos atuais sobre os bibliotecários do domínio jurídico no estado de São Paulo, tendo em vista a apresentação de seus perfis e serviços atuais. A pesquisa mais recente sobre o assunto apresenta dados do Distrito Federal, por Baptista et al. (2008), as autoras sugerem que os mesmos questionamentos por elas levantados na época, sejam aplicados à outras regiões do Brasil. Até o momento, verificou-se que não há pesquisa atual que reúna este tipo de informação sobre os bibliotecários jurídicos no estado de São Paulo, o que motivou a elaboração do presente artigo.

O objetivo foi proporcionar bibliografia atualizada sobre o bibliotecário jurídico, sua formação e os serviços que oferecem, por meio de seu perfil, contribuindo diretamente para a área de Ciência da Informação, especificamente para a Biblioteconomia jurídica.

Como objetivo específico, buscou-se prover dados quantitativos e qualitativos atualizados sobre a formação e profissão do bibliotecário nesse domínio específico, proporcionando o levantamento dos serviços prestados com mais frequência em suas rotinas diárias. Na discussão dos resultados, será feita uma comparação da análise dos dados desta pesquisa, com os dados do artigo de Baptista et al. (2008).

O método utilizado consiste em pesquisa etnográfica, por meio da aplicação de questionários a bibliotecários que atuam na área jurídica no estado de São Paulo. Com a análise dos dados obtidos, pretende-se entender o perfil atual e serviços diários dos bibliotecários jurídicos desta região específica.

A seguir, serão apresentados conceitos sobre o bibliotecário, sua formação acadêmica e sua atuação na área jurídica. Na seção 3 , serão apresentados os procedimentos metodológicos. A seção 5 apresenta a análise dos dados coletados e a discussão dos resultados da pesquisa. O objetivo é conceituar o bibliotecário jurídico e seu perfil, apresentando resultados coletados com base em levantamento bibliográfico e coleta de dados etnográficos. Busca-se conhecer as funções, o campo de atuação e os serviços deste profissional altamente especializado.

\section{0 bibliotecário jurídico, sua formação e atuação}


A formação do bibliotecário pode ser estudada de sob várias dimensões, como a profissional, a cidadã, a investigativa e a comunicativa (GUIMARÃES, 2000, p. 55). Considera-se nesta pesquisa, a dimensão profissional, que tange tanto os aspectos relacionados à realidade informativa pautada em suportes documentais e no papel de organização e disponibilização (ou transferência) de informação para geração de conhecimento, quanto aos elementos relativos à atuação profissional (GUIMARÃES, 2000, p. 56). Os aspectos relacionados à organização e disponibilização de informação são aprendidos por meio de teoria, na educação superior, e os aspectos relativos à atuação profissional, são aprendidos com a experiência no mercado de trabalho.

\subsection{A formação}

O bibliotecário jurídico é um profissional muito especializado. Sua formação se dá via curso superior na área de Humanidades, e sua profissão é regulamentada pelo Conselho Federal de Biblioteconomia - CFB e pelos Conselhos Regionais de Biblioteconomia - CRB.

Paiva et al. (2017, p. 3) afirma que a "formação do Bibliotecário se dá através de curso de nível superior, ou seja, bacharelado em Biblioteconomia, com tempo de duração médio de 4 anos [...] a educação formal desse profissional só aparece no Século XIX".

Segundo o Parecer CNE/CES no492 de 2001, os conteúdos curriculares dos cursos de Biblioteconomia dividem-se em gerais e específicos. Os gerais objetivam a aquisição de conhecimentos basilares a formação humanística da profissão, agregando uma perspectiva social e cultural aos bacharéis. Já os conteúdos específicos visam conferir habilidades de caráter técnico inerentes ao fazer bibliotecário. (BRASIL. MINISTÉRIO DA EDUCAÇÃO, 2001, p. 33 apud PAIVA et al., 2017, p. 5).

Cabe aos cursos formadores, sejam de graduação ou de aspecto técnico, o dever de "disponibilizar todo e qualquer tipo de tecnologias ao seu corpo docente e discente, buscando um ensino-aprendizagem que permita ao profissional atuar no mercado de trabalho de forma segura e competente" (VALENTIM, 2000, p. 20). E cabe ao profissional, o esforço e busca pela educação continuada, visando excelência profissional.

Ao analisar autores citados, se fez necessário conceituar o bibliotecário jurídico sob vários aspectos. Passos (2001, p. 1) define o bibliotecário jurídico como responsável por facilitar o acesso dos usuários à informação jurídica.

A produção da informação jurídica tem alcançado grandes proporções com a intensificação da produção doutrinária e da constante publicação de leis (MIRANDA; MIRANDA, 2017, p. 78), jurisprudência e doutrina. 
Guimarães entende que "se antes a atividade do bibliotecário podia ficar restrita aos limites físicos de uma biblioteca e de uma coleção, agora o uso difundido da tecnologia a serviço da informação transpõe barreiras físicas e institucionais" (1997, p. 126).

Para Valentim, a atualização contínua do profissional da informação é fundamental, e considera que a formação básica é absolutamente fundamental, na medida em que o indivíduo apreende a relacionar a teoria e a praxis antes de atuar no mercado de trabalho (VALENTIM, 2000, p. 21).

Entende-se, então, que o bibliotecário que atua na área jurídica necessita especializarse por meio de cursos específicos e/ou adquirindo experiência durante a sua atuação. Raramente o profissional é ensinado durante o curso de graduação sobre as peculiaridades de sua atuação no domínio jurídico.

Foram consultadas as grades ou matrizes curriculares de alguns dos principais cursos de Biblioteconomia do estado de São Paulo, em busca de disciplinas obrigatórias ou optativas relacionadas à especialização na área jurídica:

- Com carga horária total de 2600 horas, a grade de $2017^{3}$ do curso de Biblioteconomia e Ciência da Informação da Fundação Escola de Sociologia e Política de São Paulo (FESPSP), apresenta disciplinas em seis períodos, nenhuma relacionada ao domínio jurídico. A FESPSP ofereceu em 2017, um curso de extensão, intitulado: Documentação jurídica: das fontes à organização da informação ${ }^{4}$, destinado a bibliotecários, estagiários, auxiliares e demais profissionais que trabalham em bibliotecas e/ou arquivos de escritórios de advocacia e demais centros de informação jurídica, e também para os interessados em iniciar na área. A FESPSP fica na cidade de São Paulo;

- A estrutura curricular vigente de $2013^{5}$ do curso de Biblioteconomia da UNESP Universidade Estadual Paulista é apresentada em oito períodos. Possui, além das disciplinas obrigatórias e optativas, atividades acadêmicas científicas e culturais, e estágio curricular. Não há disciplina relacionada à Biblioteconomia jurídica. Localizada na cidade de Marília, interior do estado de São Paulo;

- O curso de Biblioteconomia da Escola de Comunicações e Artes da USP - Universidade de São Paulo possui grade curricular ${ }^{6}$ de 2310 horas somente para o cumprimento de disciplinas, também em oito períodos. Não apresenta disciplina específica sobre o domínio jurídico. A USP está localizada na cidade de São Paulo;

\footnotetext{
3https://www.fespsp.org.br/curso/25/Biblioteconomia e ciencia da informacao ${ }^{4}$ https://www.fespsp.org.br/curso/174/documentacao juridica das fontes a organizacao da informacao 5 http://www.marilia.unesp.br/\#!/graduacao/cursos/Biblioteconomia/grade-curricular/quadro-de-disciplinas-2013/ 6https://uspdigital.usp.br/jupiterweb/listarGradeCurricular?codcg=27\&codcur=27501\&codhab=2\&tipo=N\&print=tr ue
} 
- A grade curricular ${ }^{7}$ do curso de Curso de Biblioteconomia e Ciência da Informação - BCI da UFSCar - Universidade Federal de São Carlos possui carga horária total de 2880 horas em oito períodos letivos. Não apresenta disciplinas relacionadas ao domínio jurídico, sejam optativas ou obrigatórias. Localizada na cidade de São Carlos, interior de São Paulo;

- O curso de Biblioteconomia da UNIFAI - Centro Universitário Assunção, também localizada na cidade de São Paulo, possui carga total de 2527 horas, e não apresenta disciplinas específicas deste domínio em sua matriz curricular ${ }^{8}$;

- No curso de Biblioteconomia da PUC-Campinas, também não foi observada disciplina específica. A grade do curso ${ }^{9}$ conta com oito períodos e 2524 horas totais. Localizada na cidade de Campinas, interior de São Paulo.

Percebe-se que os mais conhecidos cursos de Biblioteconomia do estado de São Paulo, não possuem disciplinas relacionadas ao domínio jurídico em suas grades curriculares.

Em artigo de 1993, e em sua tese de doutorado, Guimarães (bacharel em Biblioteconomia e em Direito) apresenta contribuições para o tratamento temático de documentos jurídicos. No entendimento do autor, o bibliotecário deve [...] centrar seus maiores esforços no processo de análise - e não no de representação como muito se discute (GUIMARÃES, 1993, p. 53). Este pensamento de Guimarães (1993, p. 53), indica que a excelência técnica não será suficiente para uma atuação adequada em domínios específicos.

\subsection{A prática no mercado de trabalho}

Além dos desafios intrínsecos à atuação em bibliotecas jurídicas, o profissional da informação que atua nesta área se depara com a constante necessidade de inovação, tendo em vista as demandas de seus usuários.

O bibliotecário jurídico deve desempenhar o papel de transmissor da informação e deve dispor do conhecimento sobre fontes básicas de informação para atingir os objetivos da atividade biblioteconômica, solucionando problemas de pesquisa (MENDES, 2010, p. 11).

Assim sendo, o bibliotecário jurídico deve entender as tecnologias atuais e as novas formas de remodelar seus serviços e processos, pois "é o conhecimento que dá sentido à informação" (LOUREIRO, 2005, p. 2). O foco somente na organização da informação já não supre as necessidades dos usuários, tornando inevitável proporcionar serviços que correspondam às solicitações dos usuários não só por informação, mas por conhecimento jurídico.

\footnotetext{
${ }^{7}$ http://www.bci.ufscar.br/o-curso/grade-curricular ${ }^{8}$ http://www.unifai.edu.br/cursos/graduacao/Biblioteconomia-bacharelado\#matriz-curricular 9 https://www.puc-campinas.edu.br/graduacao/Biblioteconomia/
} 
O bibliotecário jurídico deve concluir o curso de graduação em Biblioteconomia, proporcionando a aptidão para atuar em bibliotecas e centros de informação do domínio jurídico. A especialização em determinado domínio se dará por meio de cursos de especialização ou por meio de experiência e práticas diárias.

No próximo capítulo, serão apresentados os procedimentos metodológicos da pesquisa e detalhes sobre a coleta de dados.

\section{Procedimentos metodológicos}

A pesquisa caracteriza-se como qualitativa, descritiva, com levantamento bibliográfico e coleta de dados etnográficos. Os questionários foram aplicados aos membros do Grupo de Informação e Documentação Jurídica de São Paulo (GIDJ/SP) ${ }^{10}$, que conta com cerca de 150 participantes.

Entre os meses de dezembro/2017 e maio/2018, 32 bibliotecários responderam ao questionário. A divulgação foi realizada via lista de e-mails do GIDJ/SP (quatro lembretes), LinkedIn e Facebook das autoras (dois lembretes).

O Grupo de Informação e Documentação Jurídica de São Paulo (GIDJ/SP) foi escolhido para a seleção dos sujeitos para coleta de dados, pois reúne bibliotecários que atuam na área do Direito no estado de São Paulo.

O questionário enviado ao GIDJ/SP foi composto por 21 questões que distinguem os profissionais por formação, faixa salarial, tempo de experiência na área jurídica e tipo de atividades exercidas no trabalho. As questões foram elaboradas com base no questionário de Baptista et al. (2008). As respostas foram comparadas e algumas apresentadas em gráficos.

Os dados obtidos com as respostas dos questionários foram analisados e apresentados na seção 4. Para a análise dos dados, as questões foram organizadas em cinco categorias com o objetivo de agrupar os dados por tema e melhorar a visualização. As categorias são: perfil dos bibliotecários, informações acadêmicas, informações profissionais, informações sobre a biblioteca e experiência na profissão.

\section{Análise dos dados e resultados}

Neste capítulo, serão apresentadas as categorias de análise, criadas com base nas respostas do questionário. As respostas que possuíam mais de duas opções, foram também apresentadas em gráficos. A discussão dos dados analisados será apresentada no próximo capítulo.

\footnotetext{
${ }^{10}$ http://www.gidjsp.com.br/
} 


\subsection{Perfil dos bibliotecários}

Faixa etária: Dos 32 bibliotecários que responderam ao questionário, com forme gráfico 1, a maior parcela se enquadra na faixa etária de 36 a 40 anos de idade ( $34 \%$ dos que responderam). Na sequência, observa-se que $19 \%$ dos bibliotecários possuem de 51 a 55 anos. A terceira e quarta parcelas são as de 31 a 35 anos, e de 41 a 45 anos, com 13\% dos respondentes em cada.

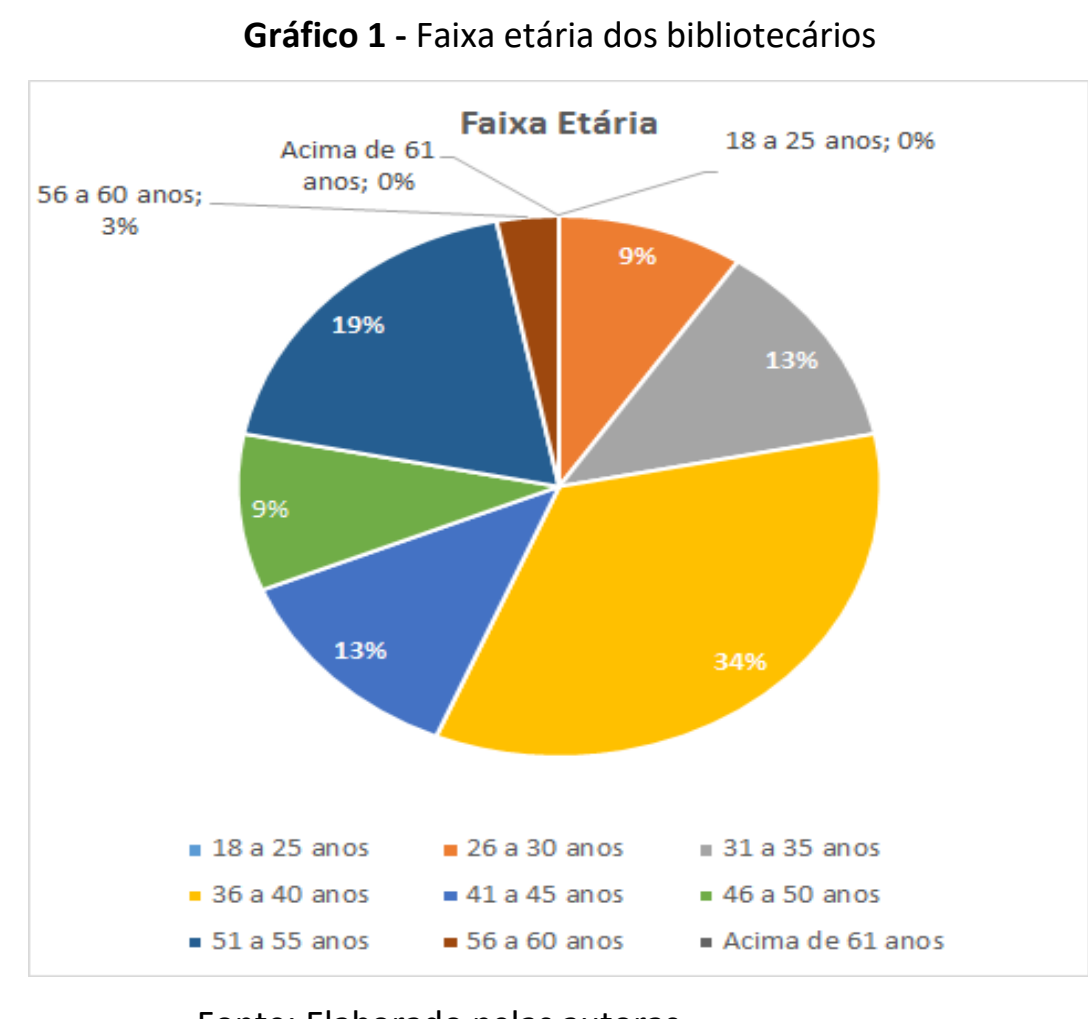

Fonte: Elaborado pelas autoras.

Gênero: Apenas 6\% dos entrevistados são do gênero masculino, enquanto a grande maioria dos bibliotecários jurídicos são do gênero feminino (94\%).

\subsection{Informações acadêmicas}

Instituição de graduação: $47 \%$ dos bibliotecários jurídicos que atuam no Estado de São Paulo, conforme gráfico 2, são graduados em Biblioteconomia e Ciência da Informação pela FESPSP Fundação Escola de Sociologia e Política de São Paulo. Na segunda posição, com 16\%, estão os bibliotecários formados na UNIFAI - Centro Universitário Assunção localizada na cidade de São Paulo, e em terceiro lugar, os bibliotecários formados na UNESP - Universidade Estadual Paulista Júlio de Mesquita Filho, situada em Marília - SP com 13\%. Em quarto lugar, com 6\%, estão os bibliotecários formados no curso de Biblioteconomia da USP - Universidade de São Paulo. As 
outras universidades, com 3\% cada, são: FATEMA - Faculdades Integradas Teresa Martin, UDESC - Universidade do Estado de Santa Catarina, UFSCar - Universidade Federal de São Carlos, FAINC - Faculdades Integradas Coração de Jesus, PUC - Pontifícia Universidade Católica de São Paulo, entre outras. Alguns bibliotecários não se formaram no estado de São Paulo.

\section{Gráfico 2 - Instituição de graduação dos bibliotecários}

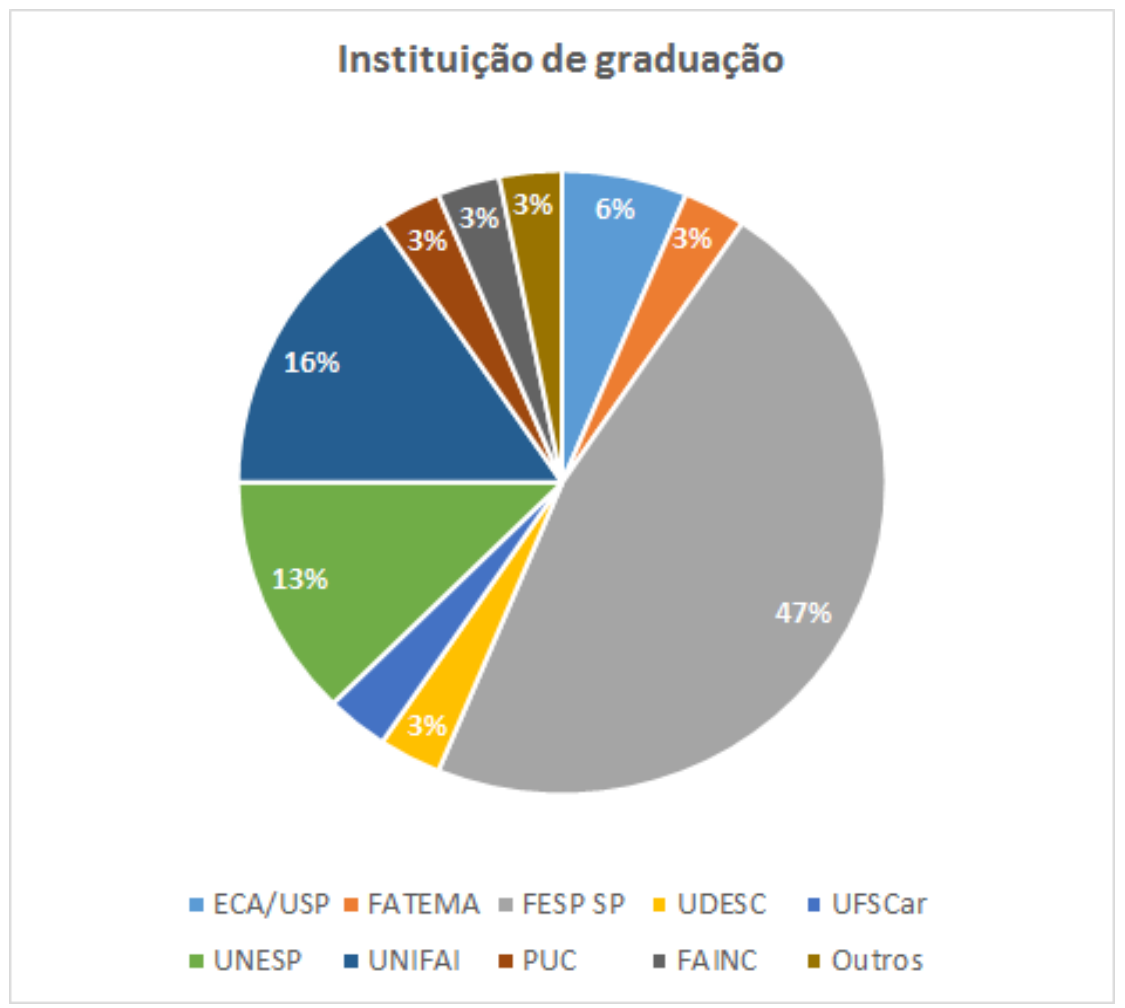

Fonte: Elaborado pelas autoras.

Ano da graduação: Com relação ao ano de formação dos bibliotecários, observa-se, conforme gráfico 3, que a grande maioria (38\%), concluiu a graduação entre 2006 e 2010. Entre 1991 a 1995, formaram-se 22\% dos profissionais da informação, de 2001 a 2005, formaram-se 19\% dos consultados e de 1996 a 2000, formaram-se 9\% dos bibliotecários. De 2011 a 2015, 6\% dos bibliotecários pesquisados se formaram, e de 1981 a 1985 e de 1976 a 1980, apenas 3\% dos bibliotecários pesquisados se formaram em cada período. 
Gráfico 3 - Ano de graduação dos bibliotecários

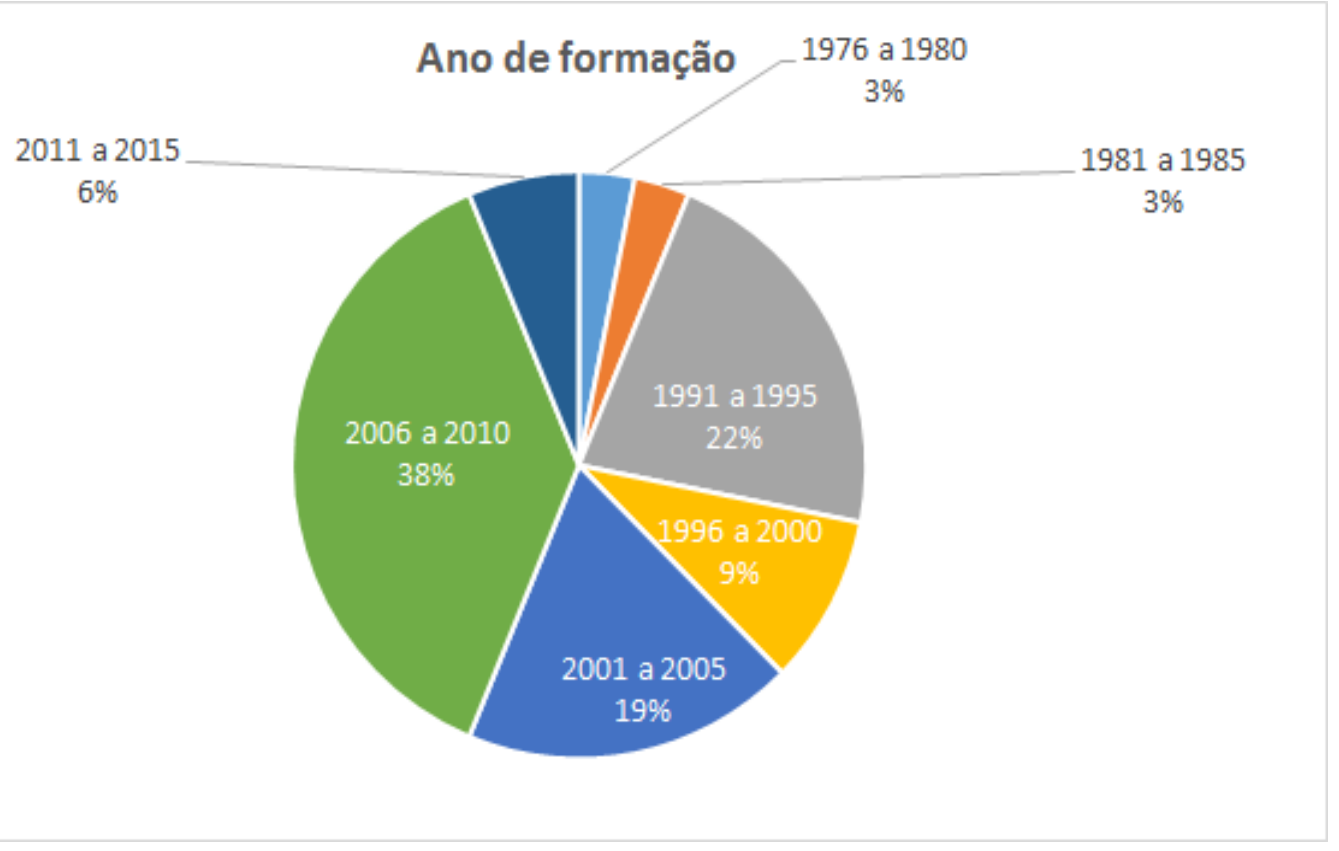

Fonte: Elaborado pelas autoras.

Formação complementar: $28 \%$ dos bibliotecários possuem outra graduação, entre os cursos, destacam-se: Pedagogia, Direito e Gestão de Recursos Humanos.

Formação de aprimoramento na área jurídica: $44 \%$ dos bibliotecários pesquisados possuem formação complementar na área jurídica. Não houve especificação nas respostas sobre o tipo, nome dos cursos frequentados e qual o motivo da realização dos cursos de especialização na área.

\subsection{Informações profissionais}

Ramo da empresa/instituição em que trabalha: $75 \%$ dos bibliotecários atuam em empresas privadas. $16 \%$ são autônomos e $9 \%$ trabalham no setor público.

Tipo da empresa/instituição em que trabalha: conforme o gráfico 4, 72\% dos bibliotecários (dos que atuam na área privada) trabalham em escritórios de advocacia de diversos portes. $16 \%$ trabalham em departamentos jurídicos das empresas em geral, enquanto $6 \%$ trabalham no Poder Legislativo, 3\% no Poder Judiciário e 3\% em órgãos não governamentais. Observa-se aqui, maior disponibilidade ou predileção pela área privada. 
Gráfico 4 - Tipo da empresa/instituição em que trabalha

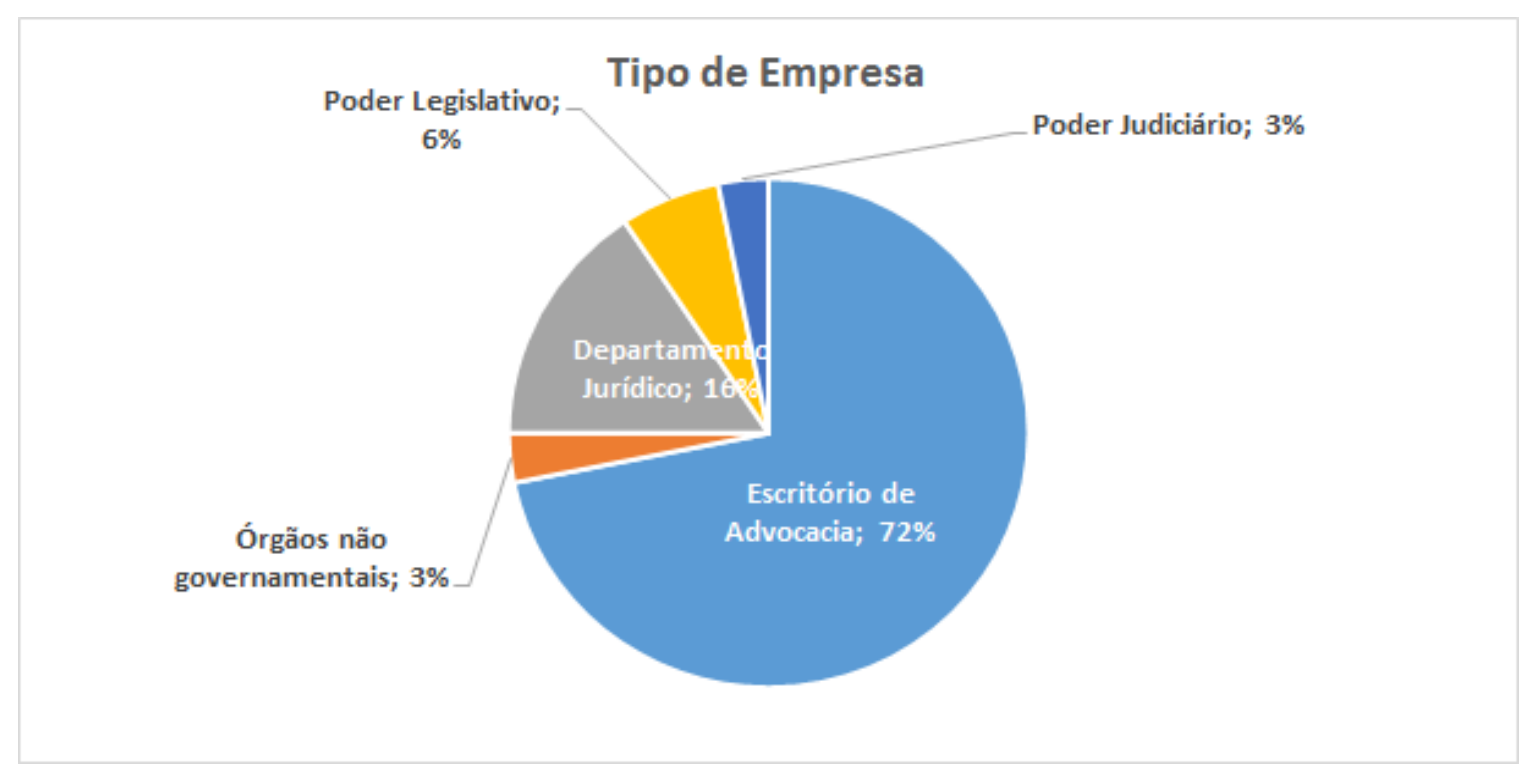

Fonte: Elaborado pelas autoras.

Faixa salarial: De acordo com o SINBIESP - Sindicato dos Bibliotecários no estado de São Paulo ${ }^{11}$, o piso para profissionais de nível superior é de $R \$ 2.850,00$. Nesta pesquisa, foram considerados apenas bibliotecários com bacharel em Biblioteconomia ou cursos equivalentes com variações de nomenclatura, porém, de acordo com o gráfico 5, mesma grade curricular. $31 \%$ dos bibliotecários recebem de $R \$ 2.001,00$ a $R \$ 4.000,00$, e $28 \%$ recebem de $R \$ 4.000,00$ a $R \$$ 6.000,00. 19\% recebem acima de $\mathrm{R} \$ 8.000,00$. 13\% recebem de $\mathrm{R} \$ 6.001,00$ a $\mathrm{R} \$ 8.000,00.6 \%$ recebem menos de $\mathrm{R} \$ 1.000,00$ e $3 \%$ recebem de $\mathrm{R} \$ 1.001,00$ a $\mathrm{R} \$ 2.000,00$, abaixo do piso estipulado pelo sindicato da categoria.

${ }^{11}$ http://www.sinbiesp.org.br/index.php/noticias/132-remuneracaopiso-salarial 
Gráfico 5 - Faixa salarial

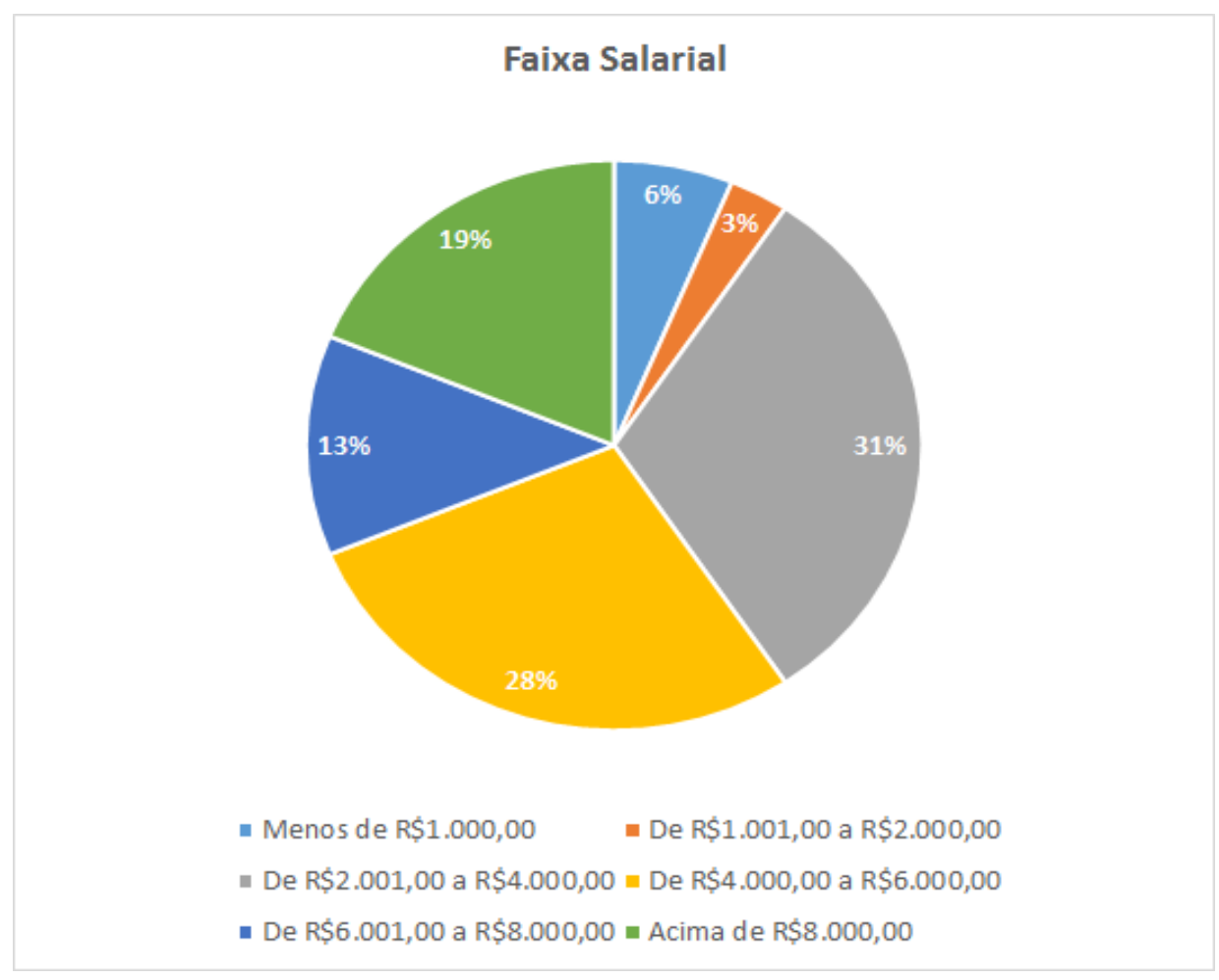

Fonte: Elaborado pelas autoras.

\subsection{Informações sobre a biblioteca}

Softwares de gestão do acervo: $38 \%$ dos bibliotecários usam o software $A B C D, 19 \%$ usam o Sophia, e $9 \%$ usam o BNWeb.

Serviços realizados pelos bibliotecários: Dos serviços realizados, de acordo com o gráfico 6, os mais comuns são os processos de tratamento temático e de forma de documentos, como a classificação com 94\% e catalogação de forma com 91\%. Na sequência, observa-se serviços puramente relacionados ao domínio jurídico, com $84 \%$, os clippings de notícias e também, com $84 \%$, pesquisas jurídicas diversas (não houve especificação de quais tipos de documento). Três serviços são realizados por $72 \%$ dos bibliotecários, sendo eles a indexação/catalogação de assunto de documentos, desenvolvimento de coleções e gestão de assinaturas diversas. Em menor escala, observamos os serviços de gestão de intranets, portais e sites, gestão do conhecimento e pesquisa de mercado. Com base nos dados apresentados, observa-se uma tendência de demanda e de interesse crescente nos últimos anos pelos três últimos serviços. 
Gráfico 6 - Serviços realizados pelos bibliotecários

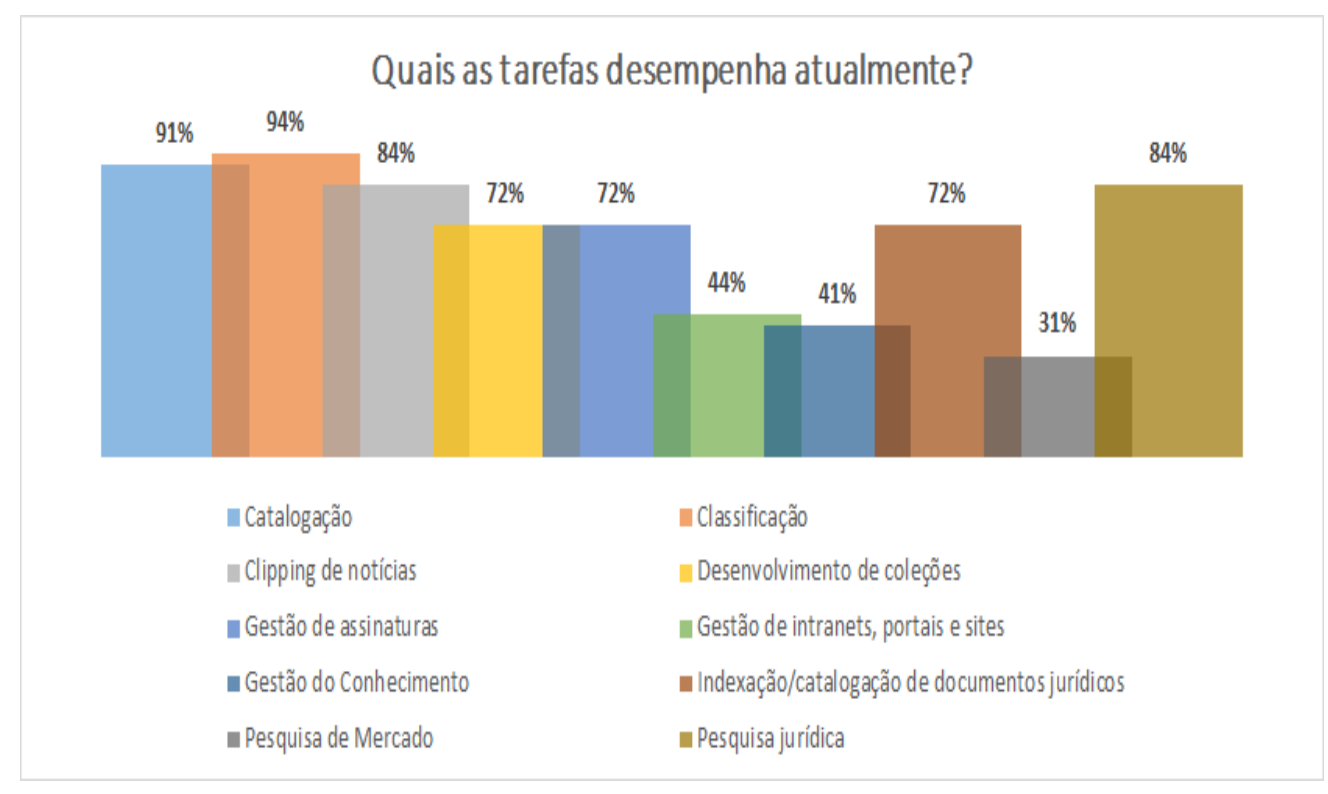

Fonte: Elaborado pelas autoras.

Tipos de documentos tratados tematicamente: Por meio do gráfico 7 se observa que $97 \%$ dos bibliotecários realizam o tratamento temático de doutrina, como livros e artigos de periódicos. 59\% dos bibliotecários realizam a catalogação de assunto ou indexação de legislação. Com 50\%, empatados, encontra-se o tratamento de jurisprudência e contratos. $16 \%$ realizam o tratamento de memorandos. $O$ tratamento temático de contratos e memorandos podem ser considerados processos para compartilhamento do conhecimento empresarial.

Gráfico 7 - Tipos de documentos tratados tematicamente

Tipos de indexação e catalogação realizados

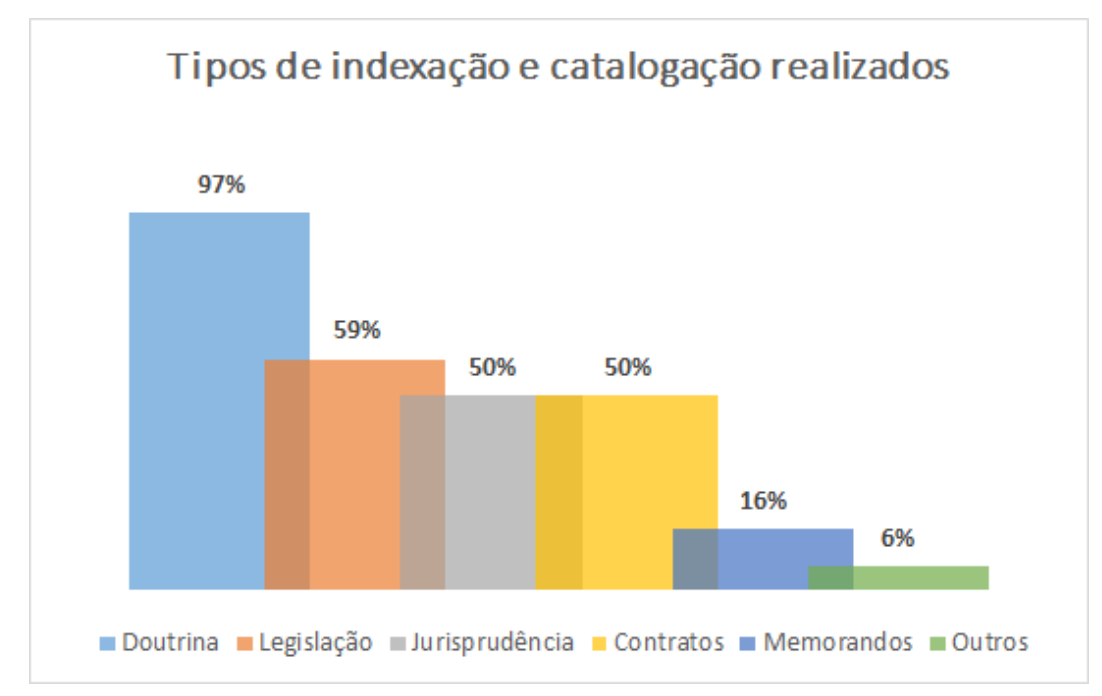

Fonte: Elaborado pelas autoras. 
Sistemas utilizados para disseminar informações aos usuários: o gráfico 8, mostra que $92 \%$ dos bibliotecários fazem uso de Intranet para compartilhar informações internas, independentemente do local de trabalho. $92 \%$ usam portais de pesquisa bibliográfica. $38 \%$ usam GED (Gerenciamento Eletrônico de Documentos), 31\% usam modelos de documentos e, em menor escala, com 19\%, wikis, blogs e sites.

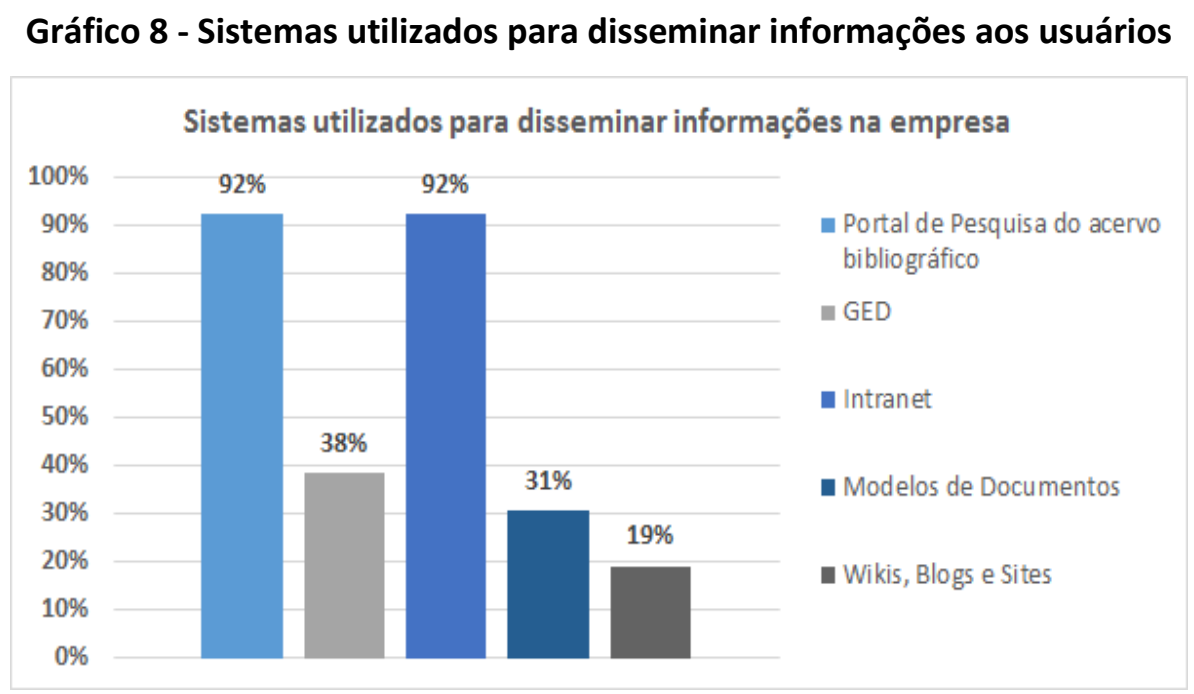

Fonte: Elaborado pelas autoras.

Uso de linguagem documentária: Observou-se que metade dos bibliotecários faz uso de linguagens documentárias, enquanto a outra metade, não.

Especificação da linguagem documentária utilizada: o gráfico 9 mostra que as linguagens documentárias mais utilizadas são: Tesauro do STJ ${ }^{12}$ (6\%), linguagem controlada própria (25\%), $25 \%$ usam Tesauro do Senado ${ }^{13}$ e $25 \%$ não informaram a linguagem utilizada.

\footnotetext{
${ }^{12}$ http://www.stj.jus.br/sCON/thesaurus/

${ }^{13}$ http://legis.senado.gov.br/webthes/
} 


\section{Gráfico 9 - Especificação da linguagem documentária utilizada}

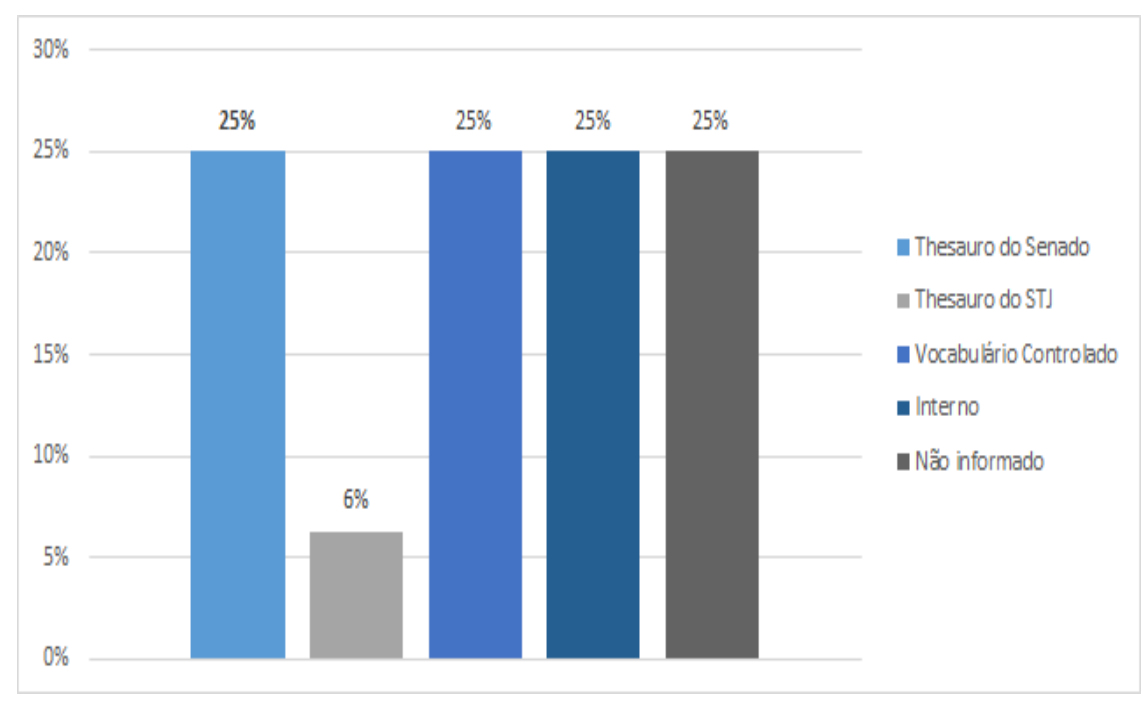

Fonte: Elaborado pelas autoras.

Orçamento das bibliotecas: Os bibliotecários possuem variados orçamentos à disposição para gastos com recursos informacionais. O gráfico 10 aponta que 31\% não souberam informar ao certo a média orçamental, $22 \%$ possuem orçamento anual de $\mathrm{R} \$ 1.000,00$ a $\mathrm{R} \$ 50.000,00$. 13\% possuem orçamento de $\mathrm{R} \$ 100.000,00$ a $\mathrm{R} \$ 200.000,00,13 \%$ possuem de $\mathrm{R} \$ 50.001,00$ a $\mathrm{R} \$$ 100.000,00. 9\% não possuem limite de orçamento e 6\% informaram que a informação é confidencial.

Gráfico 10 - Orçamento das bibliotecas

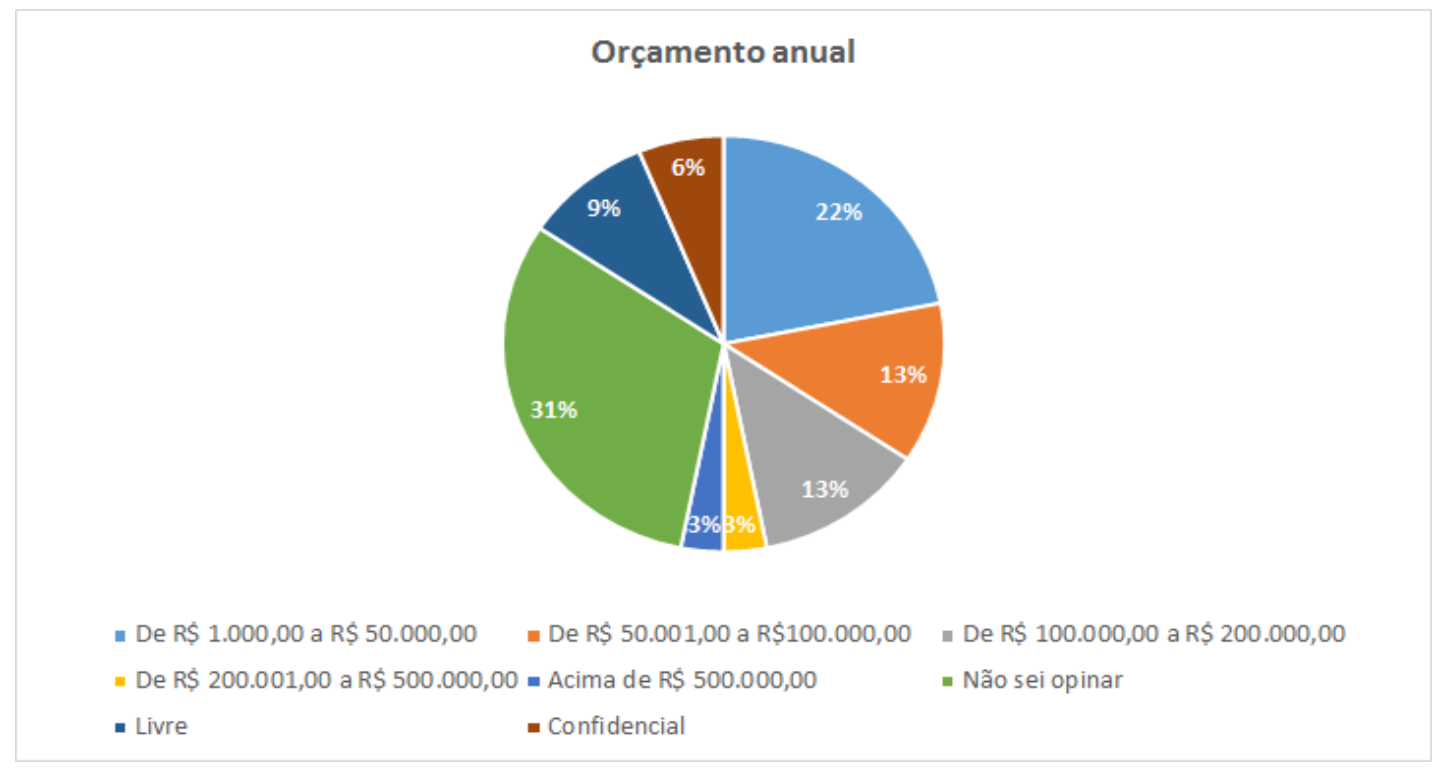

Fonte: Elaborado pelas autoras. 


\subsection{Experiência na profissão}

Maiores dificuldades ao iniciar a carreira de bibliotecário jurídico: A falta de curso especializado é a maior dificuldade vivenciada pelos bibliotecários, sendo que o gráfico 11 aponta que $53 \%$ deles enfrentam esse problema, a falta de base de dados que reúna a Legislação Federal, Estadual e Municipal vem em segundo lugar, com 44\%, e a dificuldade para assimilar termos jurídicos é a terceira maior dificuldade, com 38\%. A dificuldade em entender o processo legislativo e judiciário conta com $31 \%$, e o desconhecimento das ferramentas de pesquisa jurídica com $28 \%$. Desconhecer as fontes oficiais de informação jurídica é uma dificuldade enfrentada por $19 \%$ dos bibliotecários ao ingressar no ramo jurídico.

Gráfico 11 - Maiores dificuldades ao iniciar a carreira de bibliotecário jurídico

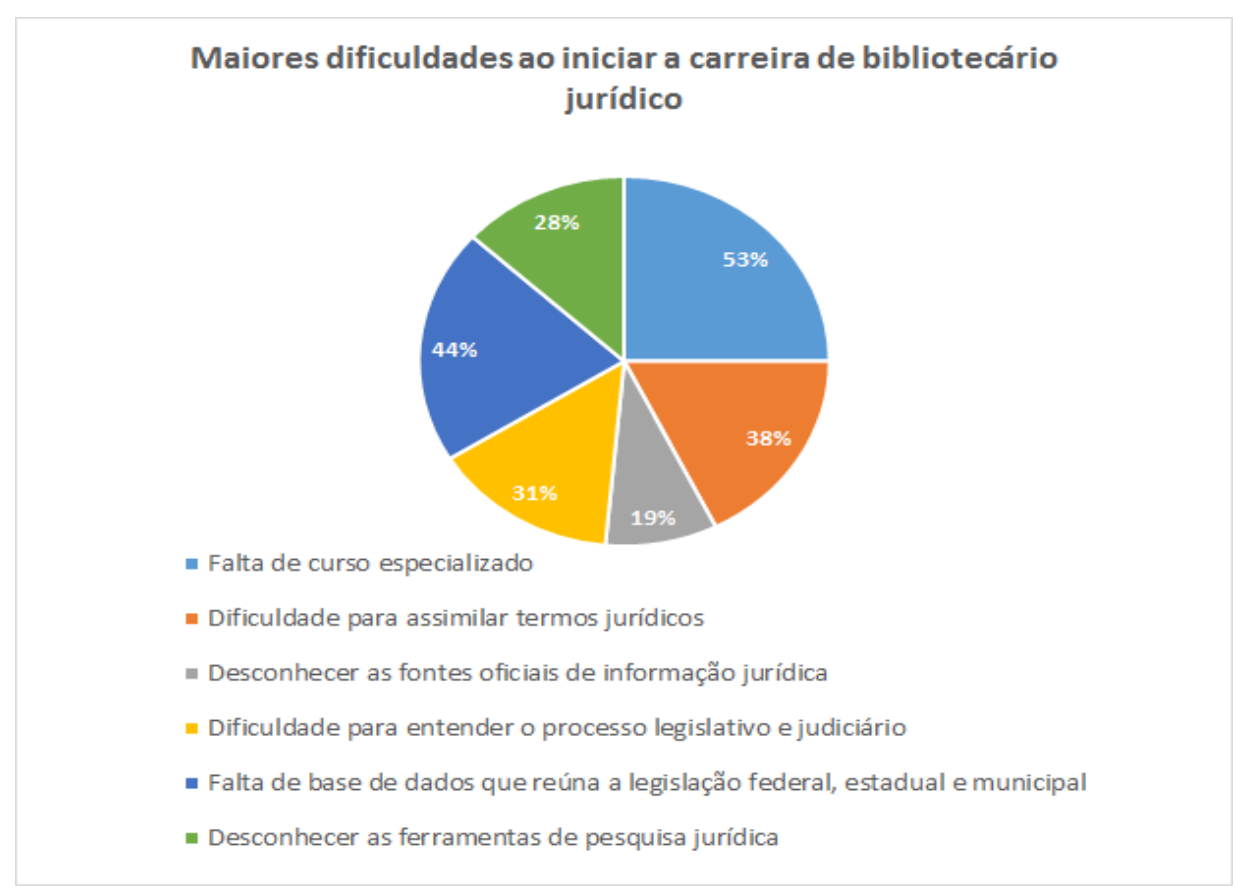

Fonte: Elaborado pelas autoras.

Tempo de experiência: 0 gráfico 12 mostra que 31\% dos bibliotecários possuem de 6 a 10 anos de experiência na área jurídica, 19\% possuem de 11 a 15 anos de experiência, 19\% estão acima dos 21 anos de experiência e outros 19\%, possuem de 16 a 20 anos de experiência na área jurídica. $13 \%$ possuem de 0 a 5 anos, a menor parcela. 
Gráfico 12 - Tempo de experiência

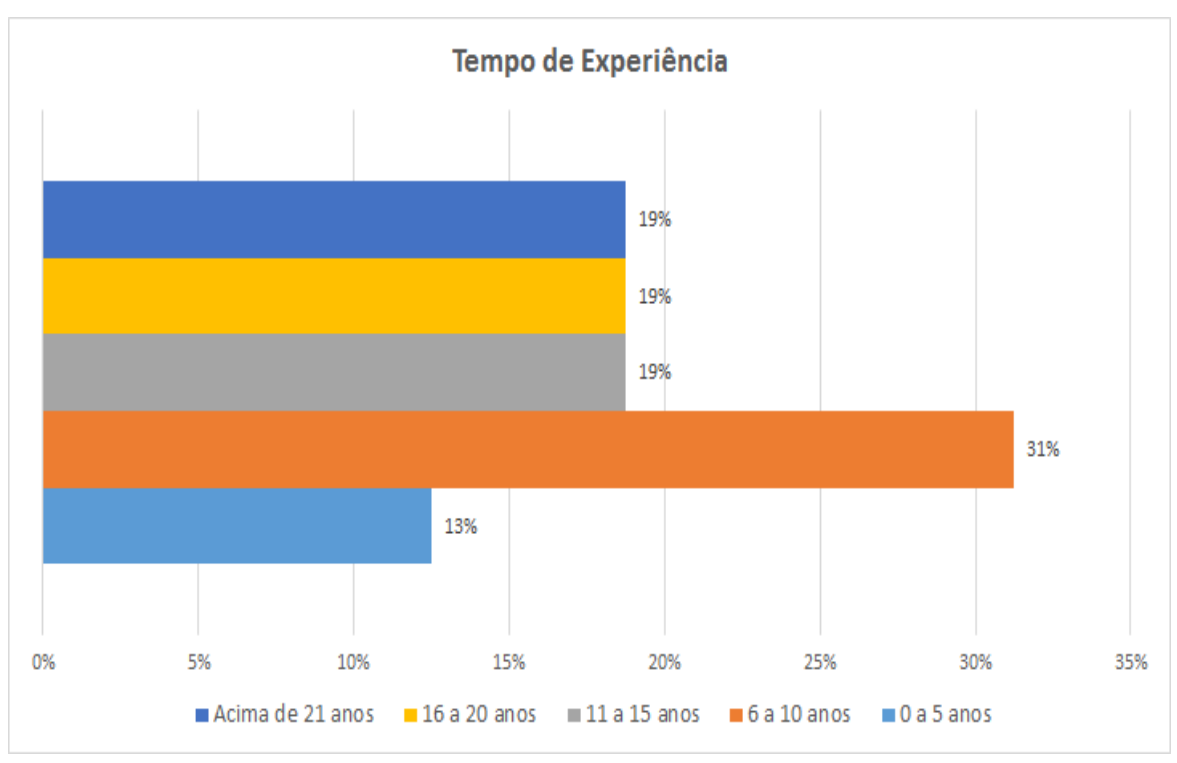

Fonte: Elaborado pelas autoras.

Média de profissionais atendidos por bibliotecário: Percebe-se que a maioria dos bibliotecários atua com poucos usuários, em ambiente de pequeno a médio porte. 0 gráfico 13 mostra que $34 \%$ dos profissionais atendem cerca de 10 a 50 profissionais. $19 \%$ atendem de 101 a 150 . Com 9\%, empatado estão os que atendem de 51 a 100, de 151 a 200, de 201 a 300, e acima de 500. $6 \%$ atendem de 301 a 500 e 3\% não opinaram.

Gráfico 13 - Média de profissionais atendidos por bibliotecário

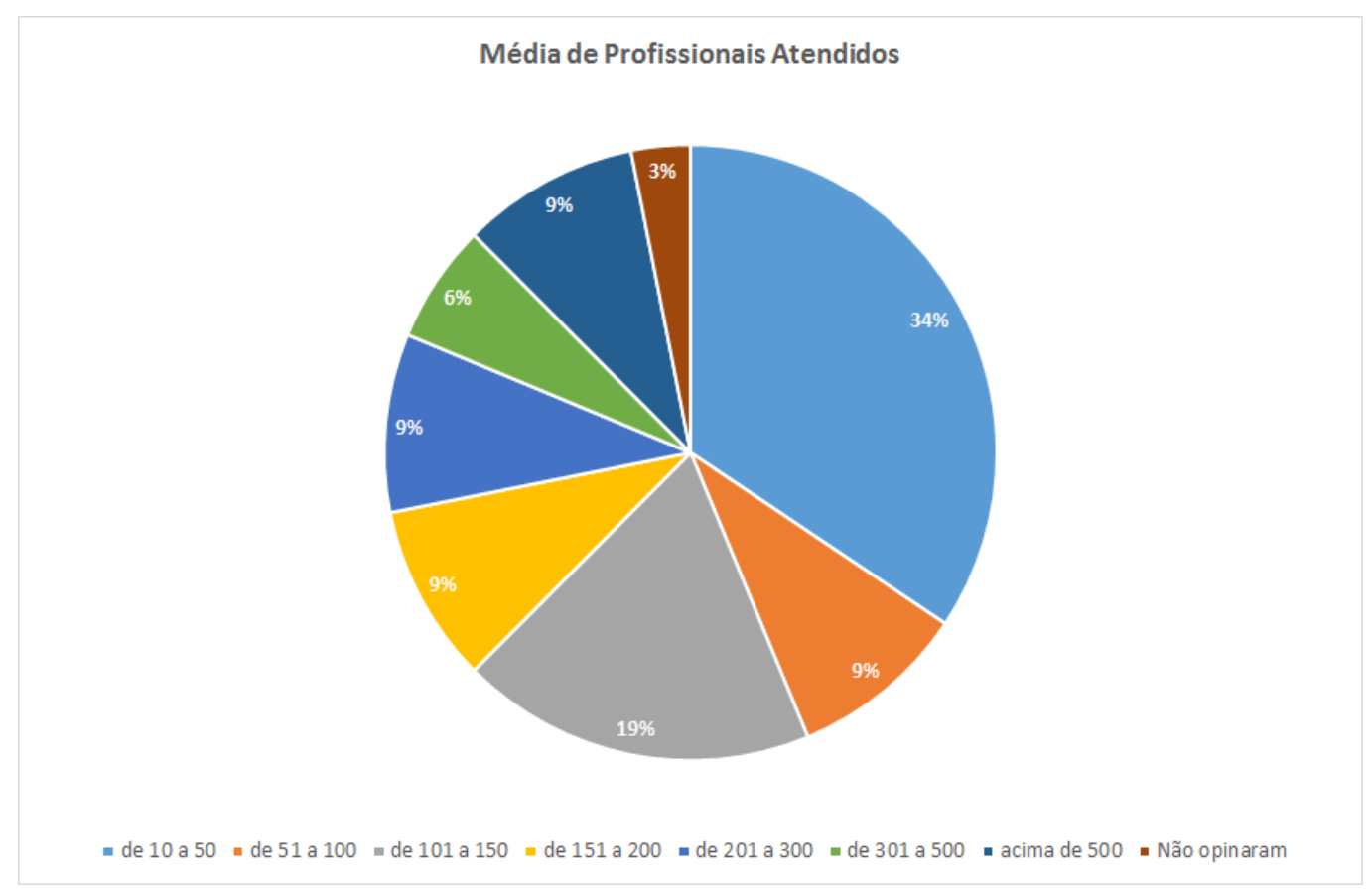

Fonte: Elaborado pelas autoras. 
Com esses gráficos, observamos que o perfil dos bibliotecários jurídicos do estado de São Paulo é composto, em sua grande maioria, por bibliotecárias na faixa etária de 36 a 40 anos, e da cidade de São Paulo.

Com relação às informações acadêmicas, a maioria dos bibliotecários são formados na FESPSP, concluíram a graduação de 2006 a 2010 e não possuem graduação em outro curso. Sobre as informações profissionais, apresentam-se como maioria, os bibliotecários que trabalham no ramo privado, em escritórios de advocacia e que ganham de $\mathrm{R} \$ 2.001,00$ a $\mathrm{R} \$$ $4.000,00$.

Nos dados sobre a biblioteca predominam os que utilizam o $A B C D$ e o BNWeb como software de gestão da informação e do conhecimento. Eles também realizam em maioria, a classificação e a catalogação de suportes informacionais e indexam/catalogam assuntos de doutrina. Grande parte responde diretamente para o sócio gestor, utilizam portais de pesquisa bibliográfica para disseminar informações e usam linguagens documentárias específicas. Prevalecem os que não sabem informar o valor orçamental disponível para a biblioteca.

A categoria relacionada à experiência dos profissionais mostra que muitos não possuem cursos de especialização. Em geral os bibliotecários possuem de 6 a 10 anos de experiência e atendem, em média, de 10 a 50 profissionais com todas suas variações de prestação de serviço.

Alguns resultados foram semelhantes aos de Baptista et al. (2008), a comparação será feita a seguir.

Na categoria perfil dos bibliotecários, em informações sobre faixa etária, percebeu-se que a maior parte dos bibliotecários do estado de São Paulo, possuem entre 36 a 40 anos, enquanto a maioria dos bibliotecários do Distrito Federal, possuem de 41 a 45 anos. Existe maior predominância de bibliotecários com idade a partir de 36 anos atuando neste domínio específico, fato que pode estar relacionado à necessidade de experiência. E com relação ao gênero, 94\% dos bibliotecários do estado de São Paulo, e 83,3\% dos bibliotecários do Distrito Federal, são do gênero feminino. Dados que demonstram a predominância de mulheres neste domínio, nos dois locais estudados (na cidade de São Paulo e no Distrito Federal na pesquisa de Baptista et al., 2008).

Na categoria informações acadêmicas, sobre a instituição de graduação, notou-se que nesta pesquisa, a maioria dos bibliotecários jurídicos são formados pela FESPSP - Fundação Escola de Sociologia e Política de São Paulo (47\%), enquanto na pesquisa de Baptista et al. (2008), predominam bibliotecários formados pela UnB - Universidade de Brasília. Com relação ao ano de graduação, no estado de São Paulo, a maior parcela dos bibliotecários se formou de 2006 a 2010 (38\%), e no Distrito Federal, 59,3\% se formou há mais de 10 anos, ou seja, aproximadamente de 1998 a 2008 (data da publicação da pesquisa de Baptista et al.). Percebe- 
se a variedade nestas informações, nos dois locais escolhidos para coleta de dados. As informações sobre formação complementar e formação de aprimoramento na área jurídica, evidenciam que existem poucas semelhanças entre os bibliotecários participantes das duas pesquisas. Poucos bibliotecários, tanto do estado de São Paulo, quanto do Distrito Federal, frequentaram cursos de graduação e/ou cursos específicos sobre a área jurídica, voltados para a atuação em bibliotecas. Não há amostra significativa nas duas pesquisas que proporcione comparação.

A categoria informações profissionais, em informações sobre o ramo da empresa/instituição em que trabalha e tipo de empresa/instituição em que trabalha, notouse que no estado de São Paulo, $75 \%$ dos bibliotecários atuam no ramo privado da economia, principalmente em escritórios de advocacia, enquanto no Distrito Federal, somente 11,1\% atuam com certeza no ramo privado, em escritórios de advocacia, e a mesma porcentagem atua em universidades (podem ser tanto privadas, quanto públicas). No Distrito Federal, percebe-se maior concentração de empregos e cargos públicos, do que no estado de São Paulo. A faixa salarial, é outro indicador que varia muito de região para região. Um fator que pode ser determinante para o valor do salário é a forma de ingresso. Nesta pesquisa, percebeu-se que os bibliotecários jurídicos atuantes no ramo público tendem a ser mais bem remunerados do que os bibliotecários no ramo privado, considerando bônus, planos de carreira, e outros benefícios (tabela 7; BAPTISTA et al., 2008, p. 167).

A categoria de informações sobre a biblioteca, é a que apresenta o maior número de indicadores, relacionados aos serviços e detalhes técnicos sobre a biblioteca. Sobre os softwares de gestão do acervo, não há correspondência com a pesquisa no Distrito Federal. Os bibliotecários no estado de São Paulo usam com mais frequência o software $A B C D$, Sophia e BNWeb. Nos serviços realizados pelos bibliotecários, observou-se em ambas as pesquisas, que os serviços mais realizados pelos bibliotecários são: pesquisa, acompanhamento de legislação, elaboração de clippings, catalogação, classificação e indexação de documentos. No indicador de tipos de documentos tratados tematicamente, constata-se que no estado de São Paulo, a maior parte dos documentos indexados são doutrina e legislação. Os outros tipos de documentos (jurisprudência, contratos, memorandos e outros) são indexados em menor quantidade. No estado de São Paulo, os sistemas utilizados para disseminar informações aos usuários, são, em grande maioria, intranets e portais de pesquisa bibliográfica. Também, observou-se que metade dos bibliotecários fazem uso de linguagem documentária. Especificando as linguagens utilizadas, as mais comuns são o Tesauro do Senado, e vocabulário controlado próprio. A maior parte dos bibliotecários não soube informar sobre o orçamento das bibliotecas. Algumas das 
informações coletadas não estão diretamente relacionadas ao perfil do bibliotecário como profissional em si, mas são relevantes no sentido em que revelam suas rotinas.

$\mathrm{Na}$ última categoria, sobre experiência na profissão, foram apresentadas as maiores dificuldades ao iniciar a carreira de bibliotecário jurídico, sendo, nas duas pesquisas: falta de curso especializado, falta de conhecimento de termos jurídicos e de fontes oficiais de informação jurídica, dificuldade em entender os processos legislativo e judiciário, e falta de base de dados que reúna legislação federal, estadual e municipal. No estado de São Paulo, nota-se a predominância de bibliotecários com tempo de experiência de 6 a 10 anos, e a média de profissionais atendidos por bibliotecário é de 10 a 50 pessoas. Isso mostra que o bibliotecário jurídico concilia o serviço de referência às tarefas de tratamento da informação.

Comparando as duas pesquisas, percebeu-se resultados muito semelhantes, principalmente com relação às atividades realizadas pelos bibliotecários em suas rotinas. Porém, alguns resultados são extremamente dependentes da região analisada, existem contrastes evidentes no Distrito Federal e no estado de São Paulo. Outros dados, foram incompatíveis para comparar as duas pesquisas, como idade, ano de graduação, entre outros.

\section{Considerações finais}

Com base no que foi elaborado em fundamentação teórica, entende-se que durante sua formação acadêmica, o bibliotecário mantém foco em incorporar conhecimento sobre os temas fundamentais para atuar no mercado de trabalho. Em sua formação superior, são abordados diversos processos relacionados ao tratamento de documentos, além da gestão de bibliotecas e centros de informação. Estes aspectos capacitam os bibliotecários a atuar em diversos tipos de biblioteca, como as escolares, universitárias, especializadas, entre outras.

As bibliotecas especializadas (como as bibliotecas jurídicas) são abordadas superficialmente durante a graduação. Fator que transfere a responsabilidade de conhecimento sobre o domínio e rotinas, ao bibliotecário durante sua experiência profissional.

Os bibliotecários que atuam na área jurídica, se deparam com grandes dificuldades no início da atuação profissional, por falta de conhecimento e/ou orientação teórica específica via curso.

O foco deste trabalho é o profissional bibliotecário, sua prática e especialização na área jurídica. Foram apresentadas informações atualizadas destes profissionais no estado de São Paulo, comparando-as aos resultados de Baptista et al. (2008).

Em comparação dos dados desta pesquisa com a pesquisa de Baptista et al., percebeuse que os universos são diferentes, porém, muito similares. Alguns resultados variavam muito, 
em ambas as pesquisas, alguns foram extremamente compatíveis nas duas pesquisas, e alguns foram observados somente na cidade de São Paulo.

Os resultados que variam são os de faixa etária, ano de graduação, média de profissionais atendidos por bibliotecário e tempo de experiência. Estes apresentam informações que são interessantes para o delineamento do perfil do bibliotecário jurídico, porém, irrelevantes na comparação de duas pesquisas em universos diferentes.

Alguns resultados estavam claramente relacionados às regiões de cada pesquisa. Cidade, instituição de graduação, tipo e ramo de empresa ou instituição de atuação, e faixa salarial, foram informações bastante divergentes. Todas estas informações estão relacionadas diretamente à região estudada em cada pesquisa, como por exemplo, a instituição de graduação. É mais comum observar bibliotecários que atuam em São Paulo e no Distrito Federal, que se formaram em universidades do próprio estado.

Os resultados que não tinham correspondência com a pesquisa de Baptista et al. (2008), estavam todos na categoria de informações sobre a biblioteca. As autoras deste artigo sentiram necessidade de coletar informações sobre softwares de gestão do acervo, tipos de documentos tratados tematicamente, responsável pela biblioteca, sistemas utilizados para disseminar informações aos usuários, uso de linguagem documentária, especificação da linguagem documentária utilizada e orçamento das bibliotecas. Os resultados são interessante e estão detalhados no capítulo 4.

Os resultados compatíveis entre as duas pesquisas, eram sobre o gênero dos bibliotecários jurídicos, com predominância de mulheres, sobre a formação de aprimoramento na área jurídica, formação complementar, dos serviços realizados, e das maiores dificuldades enfrentadas pelos profissionais. Os resultados sobre formação foram bastante conclusivos, a grande maioria dos bibliotecários não possui formação complementar, e/ou cursos de especialização na área jurídica. Acredita-se que não se deve culpar o profissional, pois como visto em fundamentação teórica, não existe uma oferta significativa e contínua de cursos sobre essa temática, tanto no Distrito Federal, como no estado de São Paulo. Esta é uma questão que também afeta os indicadores sobre "maiores dificuldades" dos bibliotecários, problema que poderia ser resolvido com mais conhecimento sobre o domínio (adquirido via cursos).

Conclui-se que tanto os serviços prestados pelo bibliotecário jurídico, como suas dificuldades em iniciar carreira neste domínio, são bastante semelhantes, independentemente da região. O bibliotecário jurídico permanece com o desafio de se reinventar continuamente, pensando em seus serviços, e de ser autodidata, pensando na adaptação de seus conhecimentos teóricos adquiridos na graduação, à sua atuação profissional. 


\section{Referências}

BAPTISTA, S.; PASSOS, E. J. L.; SOARES, M. G.; SOUSA, L. O perfil do bibliotecário que atua na área jurídica, no Distrito Federal: relato de pesquisa. Revista Ibero-americana de Ciência da Informação (RICI), Brasília, v. 1, n. 2, p. 151-174, dez. 2008. Disponível em:

http://repositorio.unb.br/bitstream/10482/12986/1/ARTIGO PerfilBibliotecarioArea.pdf Acesso em: 16 jan. 2019.

CARVALHO. K. O profissional da informação: o humano multifacetado. DataGramaZero. v. 3, n. 5, out. 2002. Disponível em:

http://www.brapci.inf.br/index.php/article/view/0000001268/fa81446cf2a99d84b646221ccd1

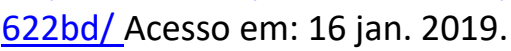

COSTA, J. R. O perfil do bibliotecário que atua nas bibliotecas dos tribunais de justiça do Brasil. 2010. TCC (Graduação em Biblioteconomia) - Faculdade de Biblioteconomia e Comunicação, Universidade Federal do Rio Grande do Sul, Rio Grande do Sul, 2010. Disponível em: https://www.lume.ufrgs.br/bitstream/handle/10183/27836/000766902.pdf?sequence=1 Acesso em: 16 jan. 2019.

CUNHA, M. V. Espaços de trabalho para profissionais da informação no Brasil: resultados preliminares, Marília, 2007. Disponível em:

http://www.marilia.unesp.br/sistemas/enancib/viewpaper.php?id=60 Acesso em: 16 jan. 2019.

GRUPO DE INFORMAÇÃO E DOCUMENTAÇÃO JURÍDICA DE SÃO PAULO (GIDJ/SP). Site Oficial do Grupo de Informação e Documentação Jurídica de São Paulo: (GIDJ/SP). 2017. Disponível em: http://www.gidjsp.com.br/Acesso em: 16 jan. 2019.

GUIMARÃES, J. A. C. Formas da informação jurídica: uma contribuição para sua abordagem temática. Revista Brasileira de Biblioteconomia e Documentação, São Paulo, v. 26, n. 1/2, p. 41-54, jan.,/jun., 1993. Disponível em:

http://www.brapci.inf.br/index.php/article/download/19240 Acesso em: 16 jan. 2019.

GUIMARÃES, J. A. C. Moderno profissional da informação: elementos para sua formação no Brasil. TransInformação, Campinas, v. 9, n. 1, p.124-137, abr. 1997. Disponível em: http://periodicos.puc-campinas.edu.br/seer/index.php/transinfo/article/view/1597 Acesso em: 16 jan. 2019.

GUIMARÃES, J. A. C. O Profissional da Informação sob o prisma de sua formação. In: VALENTIM, M. L. P.; DANTE, G. P.; SMIT, J. W.; GUIMARÃES, J. A. C.; SANTOS, J. P.; CUNHA, M. V.; ALMEIDA JÚNIOR, A. F. (Org.). Profissionais da informação: formação, perfil e atuação profissional. São Paulo: Polis, 2000. p. 53-70. E-book. Disponível em:

http://abecin.org.br/data/documents/VALENTIM Org Profissionais da informacao.pdf Acesso em: 16 jan. 2019.

LOUREIRO, R. C. C. A especialidade do Bibliotecário jurídico: bases para uma interação com o usuário operador do Direito. [S. l], 2005. Disponível em:

http://www.egov.ufsc.br/portal/conteudo/especialidade-do-bibliotec\%C3\%A1riojur\%C3\%ADdico-bases-para-uma-intera\%C3\%A7\%C3\%A3o-com-o-usu\%C3\%A1rio-operador-do Acesso em: 16 jan. 2019. 
MENDES, R. R. Conhecimentos básicos sobre o bibliotecário jurídico: ferramentas e fontes da informação. Rorg, Rio Grande, p. 1-19, nov. 2010. Disponível em:

http://repositorio.furg.br/handle/1/5952 Acesso em: 16 jan. 2019.

MIRANDA, A. C. C.; MIRANDA, E. S. Fontes de informação jurídica. Encontros Bibli: Revista Eletrônica de Biblioteconomia e Ciência da Informação, Santa Catarina, v. 22, n. 50, p. 76-90, dez. 2017. Disponível em: https://periodicos.ufsc.br/index.php/eb/article/view/15182924.2017v22n50p76/34698 Acesso em: 16 jan. 2019.

PAIVA, R. O.; POTHER, S. G. O bibliotecário jurídico na contemporaneidade. In: ENCONTRO REGIONAL DE ESTUDANTES DE BIBLIOTECONOMIA, DOCUMENTAÇÃO, CIÊNCIA DA INFORMAÇÃO E GESTÃO DA INFORMAÇÃO, 14., 2011, Maranhão. Trabalho científico de comunicação oral apresentado ao GT 2 - Mercado de Trabalho e organização social e política do profissional da informação. São Luiz: Maranhão: Universidade Federal do Maranhão, 2011. p. 1-15. Disponível em: http://www.egov.ufsc.br/portal/conteudo/o-bibliotec\%C3\%A1riojur\%C3\%ADdico-na-contemporaneidade Acesso em: 16 jan. 2019.

PAIVA, A. H. V.; CUNHA, J. A.; MARTINS, J. S.; SILVA, J. D. O.; SANTOS, R. M. Biblioteconomia: aspectos da formação bibliotecária no contexto brasileiro. Revista Informação na Sociedade Contemporânea., Natal, v. 1, n. 2, p. 1-19, jul. 2017. Disponível em:

https://periodicos.ufrn.br/informacao/article/view/11578 Acesso em: 16 jan. 2019.

PASSOS, E. J. L. Bibliotecário jurídico: seu perfil, seu papel. In: ENCONTRO DE DOCUMENTAÇÃO E INFORMAÇÃO JURÍDICA, 3., Rio de Janeiro, 2001. Rio de Janeiro: Grupo de Informação e Documentação Jurídica do Rio de Janeiro, 2001. Disponível em:

http://www.infolegis.com.br/wa files/perfilbibjuridico.pdf Acesso em: 16 jan. 2019.

SINDICATO DOS BIBLIOTECÁRIOS NO ESTADO DE SÃO PAULO (SINBIESP). Remuneração/piso salarial. 2018. Disponível em: http://www.sinbiesp.org.br/index.php/noticias/132remuneracaopiso-salarial Acesso em: 18 jan. 2018.

VALENTIM, M. L. P. O moderno profissional da informação: formação e perspectiva profissional. Encontros Bibli: revista eletrônica de Biblioteconomia e ciência da informação, Florianópolis, v. 5, n. 9, p. 16-28, ago. 2000. Disponível em: https://periodicos.ufsc.br/index.php/eb/article/view/1518-2924.2000v5n9p16/5058 Acesso em: 16 jan. 2019. 